\title{
ROMAN AND BYZANTINE MOTIFS IN CKA3AHИE О КНЯЗЬЯХ ВЛАДИМИРСКИХ (THE TALE OF THE PRINCES OF VLADIMIR)*
}

\author{
DANA PICKOVÁ
}

\begin{abstract}
Vasily III and to a greater extent Ivan the Terrible based their policies on a historical work known as Сказание о князьях владимирских (The Tale of the Princes of Vladimir). Its author attempted to find a connection between the House of Rurikids and the Byzantine and the ancient Roman Empire, although in a completely different context than monk Philotheus of Pskov who invented the idea of eternal Moscow as the third Rome. According to the concept of the author of Сказание, Rurik was a descendant of Prus, a relative of Roman Emperor Octavianus Augustus while Vladimir II Monomakh was said to obtain the insignia of imperial power from the Byzantine Emperor Constantine IX Monomakhos.

Keywords: Сказание о князьях владимирских; genealogical legend; origin of Rurikid dynasty; Roman Empire; Octavianus Augustus; gifts of Monomakhos
\end{abstract}

The second half of the $15^{\text {th }}$ century represents an important period in the development of Russian state. Firstly, the struggle for political integration of Russian princedoms, known in the Russian historiography as gathering of Russian lands, was about to reach its conclusion, and secondly, the Russian lands were liberated from the centuries-long Tatar dominion. Furthermore, the fall of Constantinople, the spiritual centre of the Orthodox Church, by the hands of the Turks marked the final collapse of the Byzantine Empire. These developments, both within Rus' and abroad, brought with them new possibilities for the fledgling Russian state and presented it with new tasks in terms of political ideology. The growing power of the monarch and the centralisation of the state were to be explained, and the place of Rus' and Muscovy was also to be delineated within the system of foreign relations and world history. Consequently, a need arose to justify the right of Russian rulers to use the title of tsar and explain its origin.

This paper has been written at the Charles University within the programme PROGRES Q09: History - The Key to Understanding the Globalized World. 
In this context, older historiography, especially pre-revolution Russian historians, emphasises the idea of adopting the fictional Byzantine heritage in Rus'. Furthermore, they overstate the importance of marriage between Ivan III, the Grand Prince of Muscovy, and Byzantine Princess Sophia Palaiologina, ${ }^{1}$ which was according to Austrian Byzantinist Herbert Hunger, "a deliberate move on the chessboard of dynastic politics, which, coupled with the adoption of imperial double-headed eagle of the Palaiologoi dynasty and Byzantine court ceremonies, served the purpose of declaring Moscow an official successor to Constantinople or in other words the third Rome and inheritor of the second Rome on Bosphorus."2 The question of adopting the Byzantine heritage in the political life of Muscovy, however, ought to be analysed with utmost caution. ${ }^{3}$ The rulers of Muscovy assumed - albeit without much endeavour - the leading role in the Orthodox world after the fall of Byzantium. According to German researcher Edgar Hösch, they nevertheless did not aim to act as the successors to the Byzantine emperors or demonstrate their dynastic relationship to the House of Palaiologoi. ${ }^{4}$ The fall of Constantinople did not automatically result in the creation of the concept of translatio imperii from Constantinople to Moscow, even though according to Russian historian Nina Vasilevna Sinitsyna this opinion is quite widespread. ${ }^{5}$

The dynastic alliance of Ivan III with a princess related to the last ruling Byzantine emperors certainly enhanced prestige of the monarch who, at that time, was ruling the still not completely consolidated Russian state. Nevertheless, the official explanation of the Muscovian monarchs' right to rule had different foundations. The new concepts did not emerge immediately after the fall of Constantinople but rather towards the end of the $15^{\text {th }}$ century, that is in the last years of Ivan III's rule (1462-1505). They were further developed during the reign of his son Vasily III (1505-1533) and grandson, the first Russian Tsar Ivan IV the Terrible (1533/1547-1584). The rationale behind Muscovian rulers' position was based on wide-spanning historical argumentation which was utilised in contemporary historical and publicistic works as well as in official documents. Although any reference to the dynastic alliance or adoption of imperial power is missing, the idea of Muscovy claiming the legacy and heritage of the Byzantine and the ancient Roman Empire had by that time already appeared.

American historian Jack Haney noted that the effort to formulate the state ideology of Muscovy lead to the creation of three different theories in the late $15^{\text {th }}$ and the early $16^{\text {th }}$ century. ${ }^{6}$ The first one centred around Moscow perceived as the new Constantinople and Ivan III (alternatively Vladimir I) as the new Constantine the Great. This idea was presented by Zosimos, the metropolitan of Moscow, in his writing Изложение пасхалии (Computus) in 1493. ${ }^{7}$ Such a concept did not appear in Rus' for the first time, for it

1 Klyuchevsky (1937: 129). A more detailed overview can be found in the monograph by Savva (1901: 1-26). This assessment only rarely appears in contemporary historiography: Duncan (2000: 12).

2 Hunger (1965: 377).

3 Opinions that the influence of Sophia Palaiologina and Byzantine elements in Russian political life were exaggerated and were not supported by primary sources, were voiced by several generations of researchers: Savva (1901: 28); Bazilevich (1952: 72-73 and 83); Hellmann (1969: 321-344); Hösch (1969: 6-17); Alef (1966: 1-21); Fennell (1961: 319-320).

4 Hösch (2010: 1, 11 and 13).

5 Sinitsyna (1998: 115).

6 Haney (1968: 354-358).

7 Pavlov (1880: 795-802). 
had already appeared in the middle of the $11^{\text {th }}$ century as a reaction to the adoption of Christianity by Vladimir I. It is included in a minor hagiographic work, known as Память и похвала князю русскому Владимиру (The memory and praise of Russian Prince Vladimir) allegedly written by a monk named Jacob from the Pechora Monastery in Kiev. ${ }^{8}$ Furthermore, Illarion, the future metropolitan of Kiev, compared Vladimir I to Constantine the Great in his sermon Слово о законе и благодати (The sermon on law and grace). To Illarion, Constantine represented the ideal ruler. ${ }^{9}$

In the latter case in the 1520s, a monk named Philotheus of Pskov from the Yelizarov Monastery ably presented the idea of eternal Moscow as the third Rome within the concept of translatio imperii from Rome through Constantinople to Moscow. ${ }^{10} \mathrm{He}$ based his assumption on the traditional image of world history as a history of great empires created by nations which were chosen by God to realize His intentions. Such formulations are present both in the Old Testament (Daniel's prophecy) and the New Testament (Apocalypse) and can also be found in the works of Byzantine literature. The story of humankind shall be concluded by a triumph and subsequent demise of three empires. After the fall of the third empire the Apocalypse shall begin and the Last Judgement shall take place. Two of these empires had already fallen, the old Rome accepted heresy and the new Rome - Constantinople - betrayed the Orthodoxy at the council of Florence. Therefore, the Empire of Rus' - the third and last incarnation of the eternal Roman Empire - shall become the protector of the "true" untainted faith. Through Rus', the human existence shall be completed. Philotheus praised the Muscovian ruler as a tsar and reminded Vasily III of his responsibility. In his eyes, the tsar was a ruler chosen by God to reign over the last worldly empire; someone to whom all secular and spiritual power was entrusted. He was the sole Orthodox monarch, therefore his role was that of the ruler and protector of all Orthodox believers. ${ }^{11}$

Thus, the theory of Russian ruler's autocratic power was thoroughly expressed for the first time within the Russian environment. Philotheus set it in a vast historical context Muscovy was represented as the sole inheritor of the recently fallen Byzantium and one of the three empires entrusted with historical role. The actual importance of this theory is still a matter of debate. ${ }^{12}$ While some argue that it had a profound influence on the development of both state and law, others assume that it never had a serious impact and circulated only in ecclesiastical circles. ${ }^{13}$ As stipulated by Ukrainian-American historian Serhy Plokhy, the theory of Muscovy - the third Rome is paid attention to much more in the modern historiographic literature than in the contemporary Russian literature. ${ }^{14}$ According to Haney, neither Zosimos' theory of Moscow as the new Constantinople nor Philotheus' idea of Muscovy as the third Rome were developed further, since they could not sufficiently provide reasoning behind Muscovy's claim to all lands of Rus' that were then under the Polish and the Lithuanian rule and therefore were not accepted in the Muscovite court. ${ }^{15}$ On the other hand, Israeli researcher Joel Raba and American histori-

${ }^{8}$ Likhachov, Dmitriyev, Alekseyev, Ponyrko (1997: 320).

9 Likhachov, Dmitriyev, Alekseyev, Ponyrko (1997: 48 and 50).

10 Sinitsyna (1998: 360 and 362-363).

11 For the theory of Philotheus see Sinitsyna (1998); Př́ihoda (2009: 135-173).

12 Timoshina (2005); Stremooukhoff (1953); Meyendorff (1981: 274-275).

13 Sinitsyna (1998: 327); Ostrowski (1998: 218, 219-243 and 246); Poe (2001: 412-421).

14 Plokhy (2006: 145).

15 Haney (1968: 856). 
an Rowland argued that the idea of Moscow as the New Israel was in fact more important than that of the third Rome in the $16^{\text {th }}$ and $17^{\text {th }}$ centuries. ${ }^{16}$ This idea was introduced by Vassian Rylo, the archbishop of Rostov, in 1480 in his work Послание на Угру (The message on the Ugra) addressed to Ivan III. The prince is introduced here as the liberator of New Israel's chosen Christian people from a new pharaoh, pagan Achmat. ${ }^{17}$

Vasily III and to a greater degree Ivan the Terrible based their policies on different arguments from historical work known as Сказание о князьях владимирских (The Tale of the Princes of Vladimir). ${ }^{18}$ Its author also attempted to find a connection between Russia - or more specifically between the ruling dynasty of Rurikids - and the Byzantine and the ancient Roman Empire, although in a completely different context. Therefore, the main focus of this paper is to analyse the Roman and Byzantine reminiscences in Сказание о князьях владимирских. Beside its content and possible aspirations of its author, the paper also examines the historical context within which the utilisation of Roman and Byzantine historical motifs occurred for the first time. Furthermore, my intent is to ascertain when such ideas were introduced to Russia.

Russian and Soviet historiography devoted to this piece of writing rather minor, but in effect very important, attention, especially in the context of Russian publicistic works of the first half of the $16^{\text {th }}$ century. The most important publications on this topic are represented by works of Ivan Nikolaevich Zhdanov, ${ }^{19}$ Rufina Petrovna Dmitriyeva, ${ }^{20}$ Aleksander Aleksandrovich Zimin ${ }^{21}$ and Aleksander Lvovich Goldberg. ${ }^{22}$ One of the most modern publications on the topic is a monograph by Nina Vasilevna Sinitsyna focused on the theory of Moscow as the third Rome. ${ }^{23}$

The first important idea introduced in Сказание о князьях владимирских is the narrative that Rurik was a descendant of Prus, a relative of Roman Emperor Octavianus Augustus. The second influential narrative is the story of Vladimir II Monomakh, who ruled at the beginning of the $12^{\text {th }}$ century and who was said to obtain the insignia of imperial power from Byzantine Emperor Constantine IX Monomakhos of Constantinople (1042-1055). The emperor also bid him to have himself be crowned by metropolitan as tsar.

The author begins his work with biblical events - the great flood and Noah's division of power among his three sons, as dictated by the mentality of the time. Subsequently, the author retells the story of how "Augustus" became emperor, began to rule the whole world ("cosmos"), and instituted his relatives to its individual parts. Among these was "Prus, his relative, at the shore of Visla, in the castle of Malbork, in Torun, Chvoinica and famous Gdansk and many other castles stretching up to the Neman River which flows to the sea. Prus lived for many years and saw the fourth generation of his kin. The land of Prussia was named after him. At that time a Novgorodian nobleman called Gostomysl reached the end of his life and so he summoned all rulers of Novgorod and told them: 'Men of Novgorod, let me give you an advice: send wise men to the land of Prussia and invite the

16 Raba (1995); Rowland (1996: 591-592 and 613-614).

17 Likhachov, Dmitriyev, Alekseyev, Ponyrko (1999: 396).

18 Malinina (2000: 278-289).

19 Zhdanov (1891).

20 Dmitriyeva (1955).

21 Zimin (1982 and 1972).

22 Goldberg (1976).

23 Sinitsyna (1998). 
ruler of their clans.' So they travelled to the land of Prussia and there they found a prince named Rurik from the House of Roman Emperor Augustus. And the emissaries of all Novgorod people begged him to come to their homeland and rule over them. Prince Rurik departed for Novgorod and brought with him his two brothers, one named Truvor and the other Sineus, along with his nephew Oleg. And since then, the city was called Novgorod the Great, and the magnificent prince Rurik ruled as the first of his kind." 24

Сказание offered a bold genealogical construction of Rurikid dynasty's ancient origins. The Russian chronicles, beginning with Повесть временных лет (Primary Chronicle or Tale of Bygony) traced the lineage only to Rurik himself, who supposedly ruled in Novgorod in the 860s and 870s. Сказание went further and deduced Rurik's origins from the emperor Augustus himself, or rather from his relative Prus who had been tasked by the emperor to rule the land named after him - Prussia.

Сказание then offers a brief glimpse at Rurik's great-grandson Vladimir I Svyatoslavich (980-1015) due to his role in the Christianization of the country. Much more attention was paid to Vladimir II Monomakh (Grand Prince of Kiev, 1113-1125). The work describes his campaign on Byzantine soil, during which the suburbs of Constantinople were laid waste. In so doing, the grand prince wanted to achieve the same success as his predecessors, most of all Oleg and Vseslav Igorevich, ${ }^{25}$ who had also waged war with Byzantium. Constantinople was then ruled by Constantine Monomakhos who decided to send an embassy of important secular ecclesiastic dignitaries to grand prince Vladimir Vsevolodovich: "He removed the imperial diadem from his head and placed it on a golden platter. Then he ordered a goblet to be brought made of carnelian, from which Roman Emperor Augustus liked to drink, a necklace that he wore on his shoulders, a golden chain made of Arabic gold, and many other imperial gifts." These presents were given to emissaries with the following message: "Accept, devout and god-loving prince, for your glory and honour these honourable gifts which belong from the very beginning to your kin and are its destiny, so that you could crown yourself on the throne of your won free autocratic tsardom." 26

24 Пруса, сродника своего, в брезг Висль рюие во градю Марборок, и Турнб, и Хвоини, и пресловыи Гданескъ, и инь многи грады по ргку, глаголемую Немонъ, впадшую в море. И житъ Прусъ многа вргмена лють и до четвертаго роду; и оттолю и до сего вргмяни зоветься Прусьская земля. И в то вргмя некий воевода новгородьикий именемғ Гостомысль скончеваетъ свое житье и созва вся владелиа Новагорода и рече имъ: «О мужие новгородьстии, совпть даю вамъ азб, яко да пошлете в Прусьскую землю мужа мудры и призовите от тамо сущих родов к себю владелиа». Они же шедше в Прусьскую землю и обрптоша тамо нткоего князя именемв Рюрика, сущза от рода римбскаго Августа изаря. И молиша князя Рюрика посланьниць от всехъ новгородиовъ, дабы шель к нимъ княжити. Князь же Рюрикъ прииде в Новъгород, импя с собою два брата: единому имя Труворъ, а второму Синеусъ, а третий племенникъ его именемъ Олегъ. И оттоль нареченъ бысть Великий Новградъ; и начя княз великий Рюрикъ первый княжити в немъ. My translation.

25 It seems that the actual person described in the excerpt was Svyatoslav Igorevich, Prince of Kiev who ruled between 962 and 972 .

26 Снемлет же от своея главы венець иарьский и поставляет его на блюдп злате. Повелеваеть же принести крабьииу сердоликову, из неяже Августия, иарь римбский, веселяшеся, и ожерелье, иже на плешу своею ношаше, и чепь от злата аравьска исковану, и ины многи дары иарьскиа ... Прийми от насъ, о боголюбивый благоверный княже, сиа честныа дарове, иже от начатка впчньх лють твоего родьства и поколюнья изарьский жребий, на славу и честь и на венчание твоего волнаго и самодержавнаго изарствиа. My translation. 
The second story was to justify the right of the Rurikid dynasty to claim the title of tsar since the $11^{\text {th }}$ or $12^{\text {th }}$ century. This part is dominated mainly by Byzantine motifs. The right to be crowned a tsar was personally given to the Grand Prince of Vladimir by the Byzantine emperor himself, for since the time he had sent the insignia of imperial power to Kiev, "till today's time the Grand Princes of Vladimir, when they proclaim themselves the grand princes, are given the tsar's crown sent by Constantine Monomakhos." ${ }^{27}$ The connection to the imperial Rome is thus reinforced because one of the insignia was once in the possession of Emperor Augustus himself. After all, Byzantine rulers considered themselves to be Roman emperors and their empire the direct successor of the ancient empire. Such information is nevertheless missing in Сказание - Constantine Monomakhos is titled греческий изарь (Greek tsar) or the tsar ruling in Constantinople.

There is no doubt that both stories included in Сказание are pure fiction. The more obvious case is the relation between the ruling Russian dynasty and the Roman Emperor Augustus, since there are no historical facts supporting such narrative. Nor is there any truth to the story of giving away the regal insignia. Vladimir II Monomakh was indeed a grandson of the Byzantine Emperor Constantine IX Monomakhos, ${ }^{28}$ but in the time of Constantine's death in 1055 Vladimir was less than two years old. His grandfather could therefore hardly send him the insignia, least of all in 1114, which is the date given by Сказание. ${ }^{29}$ Kievan Rus' was ruled by Vladimir's grandfather Yaroslav the Wise until 1054, when it passed to Izyaslav. Due to a complicated order of succession, whose principles are unknown to us, there was no way of knowing during the life of Constantine that Vladimir would one day become the Prince of Kiev.

It is therefore obvious that the story of Monomakh's gifts is fictional as well. Historical reminiscence converged with legends, and the past was reshaped into a form that would better serve historical arguments for ascending political doctrine of a united Russian state and its autocratic rule. Сказание о князьях владимирских offered a narrative about the ancient and noble dynastic origins of the ruling House of Rurikids, according to which they were related to the Roman emperors of antiquity. It explained the origin of the power of Russian rulers and their old claims to the title of tsar. Even though it was not explicitly stated, both legendary tales emphasised the historical relations between three political centres of medieval Russia: Kiev, Vladimir and Moscow. Furthermore, they stressed the extraordinary role of Russia that continued the ancient Roman and Byzantine tradition, and thus has taken place among famous empires of both the ancient and medieval Europe.

The concept offered by Сказание differed greatly from the theory of Moscow as the third Rome created but a few years later. The main principle was the continuity of secular power and not the preservation of the Orthodox faith, advocated by Pskovian monk Philotheus. In any case, there was no translatio imperii - no adoption of Roman emperorship or, in other words, imperial power from Byzantium to Rus' as it was formulated

27 И оттоле и донынг тюмб вюниемъ венчаются иарскимъ велиции князи володимерьстии, егоже прислал греческий изарь Коньстянтинъ Манамах, егда ставятся на великое княжение русьское. My translation.

28 In 1046 Yaroslav the Wise married a relative, possibly a daughter, of Byzantine Emperor Constantine IX Monomakhos, whose name according to the Byzantine sources was Maria or Anastasia. The couple had a son Vladimir who was born in 1053.

29 Dmitriyeva (1955: 189). 
by Philotheus. Nor was there any significance attributed to the marriage of Ivan III to the niece of the last two Byzantine emperors, and to the dynastic assumption of the Byzantine heritage. According to Сказание, the right of Russian rulers to use the title of tsar originated in the $12^{\text {th }}$ century and was awarded personally by the Byzantine emperor.

Most of Сказания о князьях владимирских manuscripts were accompanied by a text called Родословие (оr Родство) литовских князей (Genealogy of Lithuanian Princes), in which the origin of princes of Lithuania was explained. According to this source, the line of princes originated with a certain man named Gidiminik, or $p a \sigma$, a servant to the prince of Smolensk's relative who, after the prince's death, married his widow, a daughter of a beekeeper from Samogitia. The author of the text tried to show a striking contrast between the high-born Rurikids, whose ancient origin led to the Roman Emperor Augustus and the low-born Lithuanian princes or alternatively the Polish kings. The main purpose of the text was to disqualify Gediminid dynasty in terms of genealogy, since they were the main adversaries of Muscovite rulers in their struggle to claim the legacy of Kievan Rus'. ${ }^{30}$ This is also implied to a degree in the text of Родословия, which recounts the conquering of the city of Kiev, Chernigov and other ancient Russian cities by Prince Vitold.

When did the historical fiction using the Roman and Byzantine motifs in order to explain Rurikids' ancient origin and their claim for the title of tsar appear for the first time? Where did it originate? It is fairly difficult to pinpoint a precise moment in history. The tale of Monomakhos' gifts and of Emperor Augustus survived in more than thirty manuscripts, although the text varies in many cases and it is clear that there were different redactions. Apart from the variations of Сказания, ${ }^{31}$ there is a similar text known as Постание о Мономаховом вение (The Message of the Crown of Monomakhos) ${ }^{32}$ or Чудовская повесть (Повесть об Августе кесаре - Story of Caesar Augustus). ${ }^{33}$ These texts evolved over many years and were very continually expanded, modified, or reduced. This was nothing out of the ordinary as such practice was fairly common at the time in medieval Rus'. In certain cases, this practice even hinders the critical analysis of primary sources. Let us put aside the textual analysis of Сказания which was already conducted by several researchers without reaching a satisfactory or even united opinion on the date of the text's creation or the identification of the author, and attempt to embed the problem in the context of historical events. It is important to note that the part of the text this article focuses on is in individual editions more or less identical.

In 1498, the very first coronation of a Muscovite ruler took place. Ivan III himself crowned his grandson Dmitry Ivanovich with a cap and бармы. Doing so, he officially elevated him to the position of the Grand Prince of Vladimir, Muscovy and all of Russia. To our best knowledge, it was the very first act of coronation that was performed in Rus' lands and it symbolised the growing power and prestige of the Muscovite ruler. The jewel utilised for the coronation was a golden cap which had for decades rested in the vault of

\footnotetext{
30 Dmitriyeva (1955: 153).

31 There were two redactions according to Russian historian Dmitriyeva (1955: 171-178 and 185-191).

32 Dmitriyeva (1955: 159-170).

33 Dmitriyeva (1955: 196-200).
} 
Muscovite monarchs. ${ }^{34}$ At the time when there was a need for coronation insignia, the organisers searched for an appropriate jewel and actually found several pieces - among them a golden helmet of Egyptian origin, wide silk collar adorned with gold, several gems, and some religious images. Nobody apparently knew where these items originated which was convenient because a suitable legend could be crafted around these jewels. ${ }^{35}$ Simultaneously with Dmitry's coronation or soon afterwards, a legend was artificially conceived claiming that the cap and бармиı were gifts from Constantine XI Monomakhos to his grandson Vladimir II Monomakh and therefore must have been brought to Russia at the beginning of the $12^{\text {th }}$ century. Vladimir was also supposed to crown himself tsar at the behest of the Byzantine emperor. The name of the coronation jewel шапка Мономаха appears for the first time in Russian chronicles in $1518 .^{36}$

Another coronation, this time the tsarist one, took place in Moscow half a century later in 1547 when Ivan IV the Terrible was crowned. The actual successor to Ivan III, Vasily, did not organise any crowning ceremonial. It is therefore probable that the legend of Monomakhos' gifts began to materialise in connection to Dmitry's coronation at the end of the $15^{\text {th }}$ century. This opinion was shared by a known Russian historian Aleksander Aleksandrovich Zimin ${ }^{37}$ as well as other researchers of his generation such as Margarita Yevgenyevna Bychkova ${ }^{38}$ or Anna Leonidovna Khoroshkevich who noted that Сказание о князьях владимирских шаs created in 1498 but its subsequent fate is puzzling. ${ }^{39}$ I have to concur with Khoroshkevich's opinion on the topic. Nina Vasilevna Sinitsyna may have denied any connection between the creation of Сказание and Dmitry's coronation. Nonetheless she acknowledged that there are no statements in primary sources that could support such position. ${ }^{40}$

According to Dmitryeva, the text of Послание о Мономаховом вение is the original source supposedly authored by a former metropolitan of Kiev and all of Russia Spiridon, who entered monastery under the name Savva. The theory of his authorship was supported by other historians as well. ${ }^{41}$ Savva was a highly educated ecclesiastical official appointed by a Constantinopolitan patriarch, but he was not acknowledged in Moscow and spent long years as a captive in a monastery in Beloozersk. Dmitriyeva argues that it was there where he was offered to create a genealogical tree of the Grand Princes of Muscovy, and that this offer apparently originated in Muscovian ruling circles centred around Vasily III. This inspired him to write the work which is now known as Послание Спиридона-Саввы (Message of Spiridon-Savva). Dmitriyeva set the probable date of the

34 The first mention of the golden cap and barms, valuables that were kept for decades in the Muscovite treasury, comes from the testament of Grand Prince of Vladimir Ivan I Kalita, compiled in 1339. See Cherepnin (1950: 8).

35 Russian Historian Natalja Viktorovna Zhilina assumes it is out of the question that the first Russian tsar would be crowned with a jewel that was originally a gift of the Tatar khan. The cap of Monomakh was not identical to a golden helmet that was mentioned in Ivan I Kalita's testament. In her opinion, the helmet was supposedly created in Byzantium in the $13^{\text {th }}$ century and Ivan I bought it in Kaffa from Italian merchants. See Zhilina (2001: 178 and 203-205).

36 Sinitsyna (2002: 642-648).

37 Zimin (1982: 148-149 and 156-158).

38 Bychkova (2005: 660).

39 Khoroshkevich (2008: 339).

40 Sinitsyna (1998: 130).

41 Alekseev (2010). The author primarily focuses on the identity of the creator of Послание о Мономаховом вение. 
work's creation to 1520 s, with the year 1523 being the latest possible date. The original text was not found satisfactory and had to be rewritten during the time of Vasily's life. Thus the second edition of Сказание о князьях владимирских саme into being which was of a more official character. The second version was written at the beginning of the 1550 s in connection to the coronation of Ivan IV the Terrible. ${ }^{42}$ Goldberg reached a similar conclusion. ${ }^{43}$ Zimin considered Dmitriyeva's and Goldberg's hypotheses debatable and therefore labeled the text called Чудовская повесть as the protograph of Сказание. ${ }^{44}$ This discussion was subsequently joined by David B. Miller who, much like Dmitriyeva, considered the Spiridon's text to be the original one, but in regard to the dating of the following editions reached a different conclusion. In his interpretation, Spiridon's narration infiltrated the literature towards the end of the 1520s and retroactively influenced the description of Dmitryi's coronation in 1498.45

Dmitriyeva assumed that Vasilyi intended to be crowned and on that account commissioned the treatise to be written on the Roman origins of the dynasty and above all on gifts issued by Monomakhos. Already during the era of his father, the princely power began to transform its character and therefore a need arose to secure a magnificent origin allowing them to further consolidate the ruler's authority. With the assistance of this fiction he was able to rationalise his decline of Pope Leo X's offer to be crowned tsar of all Russia and the Muscovite metropolitan to be elevated to the position of patriarch in 1518 and 1519. The Grand Prince undoubtedly wanted to be titled tsar and he utilised the title in diplomatic correspondence more frequently than his father, but he was to do so on his own volition and not because he was allowed to do it by the pope or anyone else. Apart from that, Dmitriyeva assumes that Vasily further used Послание Спиридона$\mathrm{Caвb}$ in the struggle for the unification of Russian lands, above all those under Polish or Lithuanian rule. ${ }^{46}$

Undoubtedly, one can agree with Dmitriyeva's other hypothesis - Vasily III was not interested in the title of tsar, which was offered to him by the pope, and he also intended to emphasise that Russian rulers were in no need for such provision since coronations had a long-standing tradition in the lands of Rus'. Similar concerns made Ivan III decline the offer of a royal title made to him by Nicolaus Poppel, an emissary of Friedrich III of Habsburg. ${ }^{47}$ Nor did he accept the offer of a marriage between one of his daughters and Friedrich's nephew Albrecht, Margrave of Baden, since the future couple would be of unequal descent. The only appropriate partner was to be the emperor's son. Among his reasons for the decline he also states: "Our ruler is a great monarch, noble from his ancestors; and his ancestors lived from the eldest of times in love and friendship with the foremost Roman emperors who gave Rome to pope and ruled themselves in Byzantium." 48 Through this reference in instruction to his emissary he attempted to emphasise the ancient origin and nobility of the Muscovite ruling house whose members were relat-

42 Dmitriyeva (1955: 109 and 153).

43 Goldberg (1976: 209-211).

44 Zimin (1982: 149-152).

45 Miller (1998: 75-77).

46 Dmitriyeva (1955: 102-105, 108-109 and 152); Pashuto (1982: 59).

47 Pamyatniki diplomaticheskikh snosheny (1851: 12).

48 Государь наш, Великий Государь уроженый изначала от своихъ прародителей; а и наперед того оть давних лет прародители его пу изначальству были в приятельстве и в любви с передними 
ed not only to the Byzantine emperors of the last Palaiologian dynasty ${ }^{49}$ but in the times past were also in contact with Roman emperor Constantine who could be the emperor that gave Rome to the pope and ruled in Byzantium. ${ }^{50}$ This instruction was issued in 1490 , which is eight years before Dmitry's coronation and at a time when the Muscovite princedom was re-establishing contacts with its western neighbours, including the Roman emperor with whom an alliance treaty was reached. ${ }^{51}$ In other words, already at that moment Ivan III had a compelling reason to show that he was on equal terms with the kings of catholic Europe, and that the roots of his genealogy reached the Roman Emperor Augustus himself. The same goal could be reached by using the seal with double-headed eagle since this state symbol was not adopted by Muscovites from Constantinople, as is usually assumed, but was inspired by the seal of Roman emperors. ${ }^{52}$ Furthermore, the Grand Prince felt a pressing need to clarify the origin of the crown jewels which he himself put on the head of his grandson Dmitry during the ceremony. The author of Сказание о князьях владимирских, or rather his protographer, managed to accomplish this task and in addition, he also pointed to the ancient tradition of tsar's coronation in the lands of Rus'. It is therefore improbable that the original text of Сказание began to materialize during the rule of Vasily III and by his own order, as is assumed by Dmitriyeva, Goldberg or Miller, especially because he preferred to avoid coronation due to the tangled events leading to the assertion of his successorship for the Muscovite throne. ${ }^{53}$

Where did the author of the original text find inspiration for his bold fictional statements, then? According to Goldberg who built upon the conclusions made by Tatischev, the narration of Rurikid's Roman descent did not have any predecessor in the Russian literature of the time. ${ }^{54}$ During the Middle Ages, when the deep historical roots were particularly treasured, whether they be dynastic origin or documents establishing legal or property claims, ${ }^{55}$ the idea of a ruler who descended from Roman emperors or directly from Octavianus Augustus appeared several times and was not limited to the Byzantine emperors but also extended to Slavonic rulers from the Asen and Nemanjić dynasties. ${ }^{56}$ The direct inspiration may have stemmed from a Slavonic-Moldovan chronicle, writ-

Римскими Цари, которые рим отдали Папе, а сами иарствовали в Византии (Paтуatniki diplomaticheskikh snosheny 1851: 17; my translation).

49 The alliance of Rurikids and Palaialogoi was never perceived as the consequence of the union between Ivan III and Sophia Palaiologina. It was rather the marriage between Ivan's aunt Anna Vasilevna and Byzantine Emperor John VIII Palaiologos.

${ }^{50}$ I assume these were not genealogical relations as presupposed by Sinitsyna (1998: 118-121).

51 Pashuto (1982: 58-59).

52 Hellmann (1969: 337-338); Alef (1966).

53 Pickova (2015: 504-505).

54 Goldberg (1976: 205).

55 Similar approach can be noted in the case of Privilegium maius, a forgery which was created by Duke of Austria Rudolf IV the Founder (der Stifter) in order to prompt his father-in-law Charles IV to secure a privileged position in the Holy Roman Empire. The document referred to other non-existing charters which had been supposedly created by Gaius Julius Caesar and Emperor Nero for the Roman province of Noricum, situated at the location of future Austrian lands. See Lhotsky (1957: 18 and 19-20).

56 Goldberg (1976: 206). Czech king and Roman emperor Charles IV also had a meeting hall in Karlstein embellished with frescos showing the genealogical cycle of the House of Luxembourg spanning to ancient emperors and the heroes of Troy, king Priamus and his son Hector; see Friedl (1956: 22-24). Several historians of Polish origin also attempted in the $16^{\text {th }}$ century to identify Slavonic people with some of the ethnic groups mentioned in the primary sources of Antiquity. 
ten at the court of Prince Stephen III of Moldavia (1457-1504), which emphasised the Roman origins of Moldovans and their ruling dynasty. ${ }^{57}$ At the beginning of the 1580s, diplomatic relations between Muscovy and Moldova became tighter and resulted in the union of Ivan III's oldest son Ivan the Young with Stephen's daughter Yelena Voloshanka, consummated at the beginning of 1483 . The following year a young prince Dmitry was born from this marriage who was subsequently crowned the Grand Prince of Vladimir, Muscovy and all of Russia. At that time, the above mentioned Slavonic-Moldovan chronicle was probably known at the Muscovite court and was included in the Voskresenky Chronicle. ${ }^{58}$

Russian authors merged the idea of family ties between their ruling dynasty and Emperor Augustus with the story known under the name Сказание о призвании варягов (Tale of the invitations of Varangians), as retold by Russian chronicles. Their construction of Rurik's invitation to rule in Novgorod was preserved but instead of Varyag, Rurik became the descendant of a Roman named Prus, a relative of Emperor Augustus. According to Vladimir Terentyevich Pashuto and Goldberg, this legend may have emerged during the time when amicable relations between Muscovy and Teutonic Order in Prussia were being established. This time culminated in the 1517 with signing of an alliance treaty aimed against the Kingdom of Poland. ${ }^{59}$ This hypothesis, however, does not seem to be very probable.

The tale of Monomakhos' gifts appeared according to Zhdanov in Russian oral tradition during the $15^{\text {th }}$ century. ${ }^{60}$ In my opinion, whether it originated as an oral legend or as a written record, it could not come into being before the coronation of Dmitry Ivanovich in 1498. This was the first time when the public could see the golden helmet elevated to the role of a crown jewel. That means it was only then that the legend could take shape and in so doing recreate the gift by Uzbeg, the khan of the Golden Horde, to the Great Prince of Vladimir Ivan I Kalita (1328-1341). Only this time this gift started to be presented as given by emperor Monomakhos and connected to his bid to crown Vladimir as tsar.

In contrast to Philotheus' theory of the third Rome, legends included in Сказание о князьях владимирских soon manifested in political conduct. The work was utilised probably already at the time of Vasily III, even though we lack direct evidence of that. Nevertheless, Grand Prince mentioned his Roman origins to imperial envoy Sigismund von Herberstein who recounted this story in his work Rerum moscoviticarum commentarii. It was also known to him that the coronation jewel of Muscovite rulers was considered a property of Kievan prince Vladimir II Monomakh. ${ }^{61}$ Сказание was certainly used by Ivan the Terrible, for example in 1547, as a foundation for the coronation of Russian tsar, the first one in Russian history. His fame and popularity was evidenced by the fact that the historical fiction included in Сказание permeated into contemporary historiography, for example into official historical chronicles, ${ }^{62}$ the genealogy of Ivan IV completed by

57 Grekul (1976b: 55-59).

58 Grekul (1976a: 172-178); Zimin (1982: 156-157).

59 Pashuto (1982: 58); Goldberg (1976: 208).

60 Zhdanov (1891: 111-112).

61 Herberstein (2008: 44 and 122).

62 Letopis po voskresenskomu spisku (1856: 23); Tikhomirov (1965: 246). 
1555 (Государев родословеи - The Sovereign's Pedigree Book), ${ }^{63}$ or into one of the most significant literary works of that time Книга степенная изарского родословия (The Book of Degrees of the Tsarist Genealogy). ${ }^{64}$ Their influence is also manifested in diplomacy. "Our great rulers, starting with Augustus who ruled the entire world and his brother Prus to our great prince Rurik and from Rurik to the current ruler, tsar the autocrat," wrote Ivan the Terrible to the Polish king and Lithuanian Grand Prince Sigismond II Augustus in 1567, "were all autocrats and there is no one who can order them." 65 According to Khoroshkevich Сказание served even as a justification for the invasion of Moscow troops in Livonia in 1558. ${ }^{66}$ In the time of Ivan IV's coronation, the stories from Сказание were carved into the tsar's throne that stood in the Uspensky temple. The foreign diplomats such as Herberstein or other imperial emissaries such as Daniel Prinz von Buchau then spread these legends beyond the borders of Muscovite Russia. ${ }^{67}$

\section{REFERENCES}

Adrianova-Perets, V. P. (ed.), 1951. Poslaniya Ivana Groznogo [The Letters of Ivan the Terrible]. Moskva / Leningrad: Izdatel'stvo Akademii nauk SSSR.

Alef, G., 1966. 'The adoption of the Muscovite Two-Headed Eagle: A Discordant View'. Speculum 41, $1-21$.

Alekseev, A. I., 2010. 'Spiridon rekomy, Savva glagolemy (Zametki o sochineniyakh kievskogo mitropolita Spiridona)' [Spiridon rekomy, Savva glagolemy (Notes on the Works of the Kiev Metropolitan Spiridon)]. Drevnyaya Rus. Voprosy mediyevistiki 41/3, 5-16.

Bazilevich, K. V., 1952. Vneshnyaya politika Russkogo tsentralizovannogo gosudarstva. Vtoraya polovina $X V$ veka [The Foreign Policy of the Russian Centralized State. The Second Half of the XV Century]. Moskva: Izdatel'stvo MGU.

Bychkova, M. Ye, 2005. 'Motivy «Skazaniya o knya'zyakh vladimirskikh» v ofitsialnykh dokumentakh serediny XVI v.' [Motifs of "The Tale of the Princes of Vladimir" in Official Documents of the Middle of the $16^{\text {th }}$ Century]. In: D. D. Mendeleyeva (ed.), Germenevtika drevnerusskoy literatury 12. Moskva: Znak, 600-675.

Cherepnin, L. V. (ed.), 1950. Dukhovnyye i dogovornyye gramoty velikikh i udelnykh knyazey XIV-XVI vv. [Spiritual and Agreement Documents of Great and Appanage Princes from the $14^{\text {th }}-16^{\text {th }}$ Centuries]. Moskva / Leningrad: Izdatelstvo Akademii nauk SSSR.

Dmitriyeva, R. P., 1955. Skazaniye o knya'zyakh vladimirskikh [The Tale of the Princes of Vladimir]. Moskva / Leningrad: Akademiya nauk SSSR.

Duncan, P. J. S., 2000. Russian Messianism. Third Rome, Communism and After. London / New York: Routledge.

Fennell, J. L. I., 1961. Ivan the Great of Moscow. London / New York: St. Martin’s Press.

Friedl, A., 1956. Mikuláš Wurmser, mistr královských portrétů na Karlštejně [Mikuláš Wurmser, Master of Royal Portraits in the Castle Karlštejn]. Praha: Státní nakladatelství krásné literatury, hudby a umění.

63 Pashuto (1982: 59).

64 Vasenko (1908: 60 and 188).

65 Наши великие государи, почен от Аугуста кесаря, обладающего всею вселеную, и его брата Пруса и даже до великого князя Рюрика и от Рюрика до нынешнего годисаря его ияарского самодержства, все государи самодержьць и нихто же им не может указу учинити (Adrianova-Perets 1951: 260). Similar expressions can be found in other tsar's missives as well: AdrianovaPerets (1951: 158, 200-201 and 378-379).

66 Khoroshkevich (2003: 202-203).

67 Zimin (1982: 149). 
Goldberg, A. L., 1976. 'K istorii rasskaza o potomkakh Avgusta i o darakh Monomakha' [On the History of the Story of the Descendants of August and the Gifts of Monomakhos]. In: D. S. Likhachov (ed.), Trudy Otdela drevnerusskoy literatury XXX. Istoricheskoye povestvovaniye Drevney Rusi. Leningrad: Nauka, 204-216.

Grekul, F. A., 1976a. 'Istoriografiya slavyano-moldavskogo letopisaniya XV-XVI vv.' [Historiography of Slavic-Moldavian Chronicles from $15^{\text {th }}-16^{\text {th }}$ Centuries]. In: M. N. Tikhomirov (ed.), Letopisi i khroniki. Moskva: Nauka, 172-188.

Grekul, F. A. (ed.), 1976b. Slavyano-moldavskiye letopisi XV-XVI vv. [Slavic-Moldavian Chronicles of $15^{\text {th }}-16^{\text {th }}$ Centuries]. Moskva: Nauka.

Haney, J. V. A., 1968. 'Moscow - Second Constantinople, Third Rome or Second Kiev? (The Tale of the Princes of Vladimir)'. Canadian Slavic Studies 2, 354-367.

Hellmann, M., 1969. 'Moskau und Byzanz'. Jahrbücher für Geschichte Osteuropas 17, 321-344.

Herberstein, S., 2008. Sigizmund Gerbershtein, Zapiski o Moskovii. Tom I. Latinsky i nemetsky tekst, russkie perevody s latinskogo A. I. Maleina i A. V. Nazarenko, s rannenovoverkhnenemetskogo A. V. Nazarenko [Notes on Muscovy. Volume I. Latin and German texts, Russian translations from the Latin by A. I. Maleina and A. V. Nazarenko, from the Early Modern High German by A. V. Nazarenko]. Moskva: Pamyatniki istoricheskoy mysli.

Hösch, E., 1969. 'Byzanz und die Byzanzidee in der russischen Geschichte'. Saeculum 20, 6-17.

Hösch, E., 2010. 'Die Idee der Translatio Imperii im Moskauer Russland'. In: Europäische Geschichte Online. http://ieg-ego.eu/en/threads/models-and-stereotypes/model-classical-antiquity/edgarhoesch-die-idee-der-translatio-imperii-im-moskauer-russland [2017-01-17].

Hunger, H., 1965. Reich der neuen Mitte. Der christliche Geist der byzantinischen Kultur. Graz / Wien / Köln: Styria.

Khoroshkevich, A. L., 2003. Rossiya $v$ sisteme mezhdunarodnykh otnosheny serediny XVI veka [Russia in the international relations of the middle of the XVI century]. Moskva: Drevlekhranilishche.

Khoroshkevich, A. L., 2008. 'Kommentary' [Commentary]. In: Sigizmund Gerbershtein, Zapiski o Moskovii. Tom II. Stati, kommentary, prilozheniya, ukazateli, karty [Notes on Muscovy. Volume II. Articles, Commentary, Applications, Signage, Maps]. Moskva: Pamyatniki istoricheskoy mysli, 279-479.

Klyuchevsky, V. O., 1937. Kurs russkoy istorii II [Course of Russian History II]. Moskva: Gosudarstvennoye sotsialno-ekonomicheskoye izdatel'stvo.

Letopis po voskresenskomu spisku, 1856. Letopis po voskresenskomu spisku [Voskresensky Chronicle] [= Polnoye sobraniye russkikh letopisey VII]. Sankt-Peterburg: Arkheograficheskaya komissiya.

Lhotsky, A., 1957. Privilegium maius. Geschichte einer Urkunde. Wien: R. Oldenburg.

Likhachov, D. S., Dmitriyev, L. A., Alekseyev, A. A., Ponyrko, N. V. (eds.), 1997. Biblioteka literatury Drevney Rusi. Tom 1. XI-XII veka [Library of Literature of Ancient Rus. Volume 1. XI-XII century]. Sankt-Peterburg: Nauka.

Likhachov, D. S., Dmitriyev, L. A., Alekseyev, A. A., Ponyrko, N. V. (eds.), 1999. Biblioteka literatury Drevney Rusi. Tom 7. Vtoraya polovina XV veka [Library of Literature of Ancient Rus. Volume 7. The second half of the XV century]. Sankt-Peterburg: Nauka.

Malinina, A. S. (ed.), 2000. Biblioteka literatury Drevney Rusi. Tom 9. Konec XV-pervaya polovina XVI veka [Library of Literature of Ancient Rus. Volume 9. End of the XV - the First Half of the XVI Century]. Sankt-Peterburg: Nauka.

Meyendorff, J., 1981. Byzantium and the Rise of Russia. A Study of Byzantino-Russian Relations in the Fourteenth Century. Cambridge: Cambridge University Press.

Miller, D. B., 1998. 'Once Again About the Dating and Provenance of the Skazanie o Kniaz'iakh Vladimirskikh'. Russian History 25, 65-77.

Ostrowski, D., 1998. Muscovy and the Mongols: Cross-Cultural Influences on the Steppe Frontier, 1304-1589. Cambridge: Cambridge University Press.

Pamyatniki diplomaticheskikh snosheny, 1851. Pamyatniki diplomaticheskikh snosheny s imperieyu rimskoyu. Tom I. (s 1488 po 1594 god) [Monuments of Diplomatic Relations with the Roman Empire. Volume I. (from 1488 to 1594)] [Pamyatniki diplomaticheskikh snosheny Drevney Rossii s derzhavami inostrannymi]. Sankt-Peterburg: Tipografiya II Otdeleniya Y. I. V. Kantselyarii. 
Pashuto, V. T., 1982. 'Vozrozhdenie Velikorossii i sudby vostochnykh slavyan' [Revival of Great Russia and the Fate of the Eastern Slavs]. In: V. T. Pashuto, B. N. Florya, A. L. Khoroshkevich, Drevnerusskoye naslediye i istoricheskiye sudby vostochnogo slavyanstva. Moskva: Nauka, 7-68.

Pavlov, A. S., 1880. Russkaya istoricheskaya biblioteka VI, 1 [Russian Historical Library VI, 1]. Sankt-Peterburg: Arkheograficheskaya komissiya.

Pickova, D., 2015. 'Pervaya koronatsiya russkogo pravitelya v 1498 godu i vizantiyskaya traditsiya' [The First Russian Coronation in 1498 and Byzantine Tradition]. In: Cyril and Methodius: Byzantium and the World of the Slavs. 28-30 November 2013. Thessaloniki: City of Thessaloniki, 499-509.

Plokhy, S., 2006. The Origins of the Slavic Nations: Premodern Identities in Russia, Ukraine and Belarus. Cambridge: Cambridge University Press.

Poe, M. T, 2001. 'Moscow, the Third Rome: The Origins and Transformations of a "Pivotal Moment"'. Jahrbücher für Geschichte Osteuropas 49, 412-429.

Př́ihoda, M., 2009. 'Mnich Filofej a Třetí Rím. Vznik a proměny jedné ideje první poloviny 16. století' [The Monk Filofei (Philotheus of Pskov) and the Third Rome. Creation and Transformations of an Idea Dating Back to the First Half of the $16^{\text {th }}$ Century]. In: P. Gkantzios Drápelová, M. Téra, M. Př́hoda, H. Nykl, K. Sládek, Kulturní, duchovní a etnické kořeny Ruska: portréty. Červený Kostelec: Pavel Mervart, 135-173.

Raba, J., 1995. 'Moscow - the Third Rome or the New Israel?'. Forschungen zur osteuropäischen Geschichte 50, 297-307.

Rowland, D. B., 1996. 'Moscow - the Third Rome or the New Israel?'. The Russian Review 55, 591-614.

Savva, V. I., 1901. Moskovskiye tsari i vizantiyskiye vasilevsy. K voprosu o vliyanii Vizantii na obrazovaniye idei tsarskoy vlasti moskovskikh gosudarei [Moscow Tsars and Byzantine Empress. To a Question about the Influence of Byzantium on Ideas Formed the Imperial Power of Muscovy]. Kharkov: Tipografiya i Litografiya M. Zilberberg i S-vja.

Sinitsyna, N. V., 1998. Trety Rim. Istoki i evolutsiya russkoy srednevekovoy kontseptsii (XV-XVI vv.) [The Third Rome. Origins and Evolution of Russian Medieval Concept (XV-XVI Centuries)]. Moskva: Indrik.

Sinitsyna, N. V., 2002. 'O proiskhozhdenii ponyatiya «shapka Monomakha» (k voprosu o kontseptsii rimsko-vizantiyskogo preemstva v russkoy obshchestvenno-politicheskoy mysli XV-XVI vv.)' [On the Origin of the Concept of "Monomakhos' Cap" (To the Question about the Concepts of the Roman-Byzantine Succession in the Russian Political Thought XV-XVI Centuries]. In: Iz istorii russkoy kultury. Tom II. Kn. 1. Kievskaya i Moskovskaya Rus. Moskva: Jazyky slavyanskoj kultury, 642-648.

Stremooukhoff, D., 1953. 'Moscow the Third Rome: Sources of the Doctrine'. Speculum 28, 84-101.

Tikhomirov, H. M. (ed.), 1965. Letopisny sbornik, imenuyemy patriarsheyu ili nikonovskoyu letopisyu [Patriarchal or Nikon Chronicle] [= Polnoye sobraniye russkikh letopisey XII]. Moskva: Izdatelstvo Nauka.

Timoshina, Ye. V., 2005. 'Teoriya «Tretego Rima» v sochineniyakh «Filofeeva tsikla»' [The Theory of the "Third Rome" in the Works of "Cycle of Filofei"]. Pravovedeniye 2005/4, 181-208.

Vasenko, P. G. (ed.), 1908. Kniga stepennaya tsarskogo rodosloviya (1-10 stepeni grani) [The Book of Degrees of the Czarist Genealogy] [= Polnoye sobraniye russkikh letopisey XXI, 1]. Sankt-Peterburg: Tipografiya M. A. Aleksandrova.

Zhdanov, I. N., 1891. Povesti o Vavilone $i$ «Skazaniye o knya'zyakh vladimirskikh» [Stories of Babylon and "The Tale of the Princes of Vladimir"]. Sankt-Peterburg: Tip. V. S. Balasheva.

Zhilina, N. V., 2001. Shapka Momomakha. Istoriko-kulturnoye i tekhnologicheskoye issledovaniye [Monomakh's Cap. Historico-Cultural and Technological Study]. Moskva: Nauka.

Zimin, A. A., 1972. 'Antichnyye motivy v russkoy publitsistike kontsa XV v.' [Antique Motifs in Russian Publicism in the Late $15^{\text {th }}$ Century]. In: Feodalnaya Rossiya vo vsemirnoistoricheskom protsesse. Sbornik statey, posvyashchenny Lvu Vladimirovichu Cherepninu. Moskva: Nauka, 129-138.

Zimin, A. A., 1982. Rossiya na rubezhe XV-XVI stolety (Ocherki sotsialno-politicheskoy istorii) [Russia at the Turn of the XV-XVI Centuries (Essays on the Socio-Political History)]. Moskva: Mysl. 


\title{
ŘíMSKÉ A BYZANTSKÉ MOTIVY V DÍLE \\ СКАЗАНИЕ О КНЯЗЬЯХ ВЛАДИМИРСКИХ
}

Vasilij III. a především Ivan Hrozný se ve své politické praxi opírali o spis historické povahy s názvem Сказание о князьях владимирских (Vypravování o knížatech vladimirských). Jeho autor se snažil najít spojitost mezi ruskou vládnoucí dynastií Rurikovců a byzantským a také antickým římským císařstvím, ovšem ve zcela jiných souvislostech než mnich Filofej ve své teorii Moskva - třetí Řím. Podle pojetí autora Сказание byl zakladatel ruské panovnické dynastie Rurik potomkem Prusa, př́ibuzného ŕímského císaře Augusta. Kromě toho získal kyjevský kníže Vladimir II. Monomach odznaky císařské hodnosti od byzantského císaře Konstantina IX. Monomacha, který ho zároveň vybídl, aby se nechal metropolitou korunovat carem.

\author{
Dana Picková \\ Charles University, Prague \\ dana.pickova@ff.cuni.cz
}

